\title{
Research Notes
}

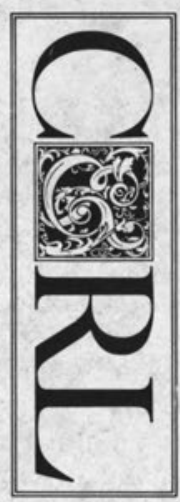

\section{Library Resources of a Metropolitan University-Assessment by Users}

\author{
James E. Prather, Ralph E. Russell, \\ and Michael L. Clemons
}

The decade of the 1970 s brought heightened public awareness on issues of accountability and program effectiveness for colleges and universities. This awareness has prompted many to examine seriously the extent to which their libraries are effectively serving students, faculty, and others. Library effectiveness may be defined in terms of each library's level of ability to respond to user needs for information and information sources within the context of its own unique situational and environmental constraints. ${ }^{1}$ Such assessment of effectiveness has proved valuable to library planning and policymaking processes, particularly in the rationale offered for augmented financial support for library operations. Increasingly, libraries and other university components must justify their budgets by measures of how well they meet the demands of their clientele. ${ }^{2}$ How better to determine the level of success for a library than by asking library users?

\section{PREVIOUS STUDIES}

Many studies have focused on the char- acteristics of library use and users. Most such studies have been concerned with public library use. The literature provides little explanation of library use in urban universities, nor have there been many attempts to study group attitudes toward library use. ${ }^{3}$ Additionally, the literature about library use in a nontraditional university and its implications for financial planning is minimal.

In a review of studies on library users, the difficulties in defining and meeting the needs of such users have been acknowledged. The diversity of a university library's user population makes difficult the definition of the needs of that population. Having defined the needs, problems in accommodating those needs are substantial. The first step, definition of user needs, however, is essential, albeit difficult and complex. It is the task frequently ignored-or abandoned to a scattershot or "guesswork" methodology. Libraries often serve clienteles other than those for which they are specifically funded. Our tradition of publicly supported, freely available public libraries has generated a

James E. Prather is senior research associate, Office of Institutional Planning, Georgia State University, Atlanta, Georgia; Ralph E. Russell is university librarian, Pullen Library, Georgia State University, Atlanta; and Michael L. Clemons is research associate, Office of Institutional Research and Planning, Atlanta Junior College, Georgia. 
widely held assumption that "libraries are free and available to all."

Few libraries serve with any frequency more than a small portion of their target population. It follows, then, that the resources allocated to a university library are expended to serve a minority of that library's target population of users. This narrow segment of users may be extremely demanding and sophisticated, but they are, nevertheless, expensive when measured against total library costs. It is imperative that library administrators and staff develop and use information regarding the types and level of use made of collections and services.

A survey of library users at a state university reported that 89 percent were affiliated with the institution. Other constituencies were students from local colleges and some general public users. ${ }^{4}$ In a study of faculty members' perceptions, the length of time at the institution influenced their attitude toward the library. ${ }^{5}$ At a community college it was found that neither level of education nor field of study were indicative of the users' attitudes about the library. ${ }^{6}$

\section{PURPOSE}

The present study examines the characteristics of library users and library use, and perceptions of library adequacy held by those users at a large, urban university. Questions include:

1. What are the institutional affiliations of the library users?

2. Are there patterns and what are the frequencies of use among various subgroupings of the university population?

3. How do various subpopulations perceive the library's adequacy?

This analysis also addresses library use by library users at a nontraditional university. The centrality of location within the metropolitan area and the abundance of other private and public colleges in the area also influence demands upon the library.

\section{METHODS}

A survey instrument was constructed by a library committee in conjunction with the institutional research staff. Based upon a pilot study, a relatively uncomplicated instrument design was used to promote questionnaire return. A random sample was stratified by day and time. Questionnaires were distributed to users as they entered the library. Surveys were administered on nine consecutive days, including two weekends, during the winter quarter. Of 6,157 questionnaires administered, 54.5 percent were returned.

\section{User Affiliation}

\section{RESULTS}

The affiliation and/or status of the library user sample is presented in table 1, where it is cross-classified with major field of study.

Affiliated Users. In a sample of 3,356 users, 85 percent indicate affiliation with the university. Affiliated undergraduate students are 51 percent of all users; affiliated graduate students are 29 percent. Faculty and alumni are each 2 percent of all users, while staff comprises 1 percent.

Unaffiliated Users. Users from a privatecollege confederation are 6 percent of all users. High-school students, members of the business community, and other nonaffiliated college students constitute the rest of this user group.

Field. More than one-third of the library users indicated their field of interest to be business administration, followed by education at 10 percent. Users in the health and sciences fields are each 8 percent of the total users. Among faculty, use by foreign-language faculty is highest (12 percent), followed by physical sciences ( 8 percent), and letters, mathematics, and social sciences, each comprising 6 percent. Library use by alumni is 7 percent in art, 10 percent in letters, 5 percent in psychology, and 3 percent in communications and public affairs. The users from the privatecollege confederation constitute 15 percent of the public affairs users, 13 percent of the social sciences, 21 percent of the biology, 9 percent of the finance, and 7 percent of the management users.

\section{Patterns and Frequency of Use}

Purpose of Visit. The cross-classifications of affiliation and/or status with responses on types of library use are presented in ta- 
TABLE 1

CROSS-CLASSIFICATION OF AFFILIATION

AND/OR STATUS WITH MAJOR FIELD OF STUDY

$(N=3356)$

\begin{tabular}{|c|c|c|c|c|c|c|c|c|}
\hline \multirow[b]{2}{*}{ Fields } & \multirow[b]{2}{*}{ Total } & \multirow{2}{*}{$\begin{array}{l}\text { Under } \\
\text { Grad }\end{array}$} & \multicolumn{2}{|c|}{ Affiliated } & \multirow[b]{2}{*}{ Staff } & \multirow[b]{2}{*}{ Alum. } & \multirow{2}{*}{$\begin{array}{l}\text { Pvt. } \\
\text { Inst. }\end{array}$} & \multirow[b]{2}{*}{ Other } \\
\hline & & & Grad & ulty & & & & \\
\hline Biology & 4 & 59 & 11 & 0 & 2 & 1 & 21 & 6 \\
\hline Bus. Admin. & 34 & 57 & 32 & 1 & 0 & 1 & 5 & 4 \\
\hline Curr. \& I. & 4 & 83 & 2 & 1 & 3 & 3 & 6 & 2 \\
\hline Info. Sys. & 4 & 66 & $2 \overline{6}$ & 1 & 0 & 0 & 3 & 4 \\
\hline Education & 10 & 29 & 62 & 3 & 1 & 1 & 1 & 3 \\
\hline Art & 3 & 64 & 12 & 2 & 4 & 7 & 1 & 10 \\
\hline For. Lang. & 2 & 58 & 23 & 12 & 2 & 0 & 0 & 5 \\
\hline Health & 8 & 70 & 15 & 3 & 0 & 0 & 2 & 10 \\
\hline Letters & 4 & 53 & 19 & 6 & 4 & 10 & 1 & 7 \\
\hline Math. & 2 & 75 & 2 & 6 & 0 & 0 & 0 & 17 \\
\hline Phy. Sci. & 2 & 64 & 16 & 8 & 0 & 0 & 0 & 12 \\
\hline Psych. & 3 & 26 & 59 & 3 & 0 & 5 & 0 & 7 \\
\hline Public Ser. & 3 & 46 & 30 & 1 & 0 & 3 & 15 & 5 \\
\hline Soc. Sci. & 8 & 52 & 23 & 6 & 1 & 2 & 13 & 3 \\
\hline Total \% & 100 & 51 & 29 & 2 & 1 & 2 & 6 & 9 \\
\hline
\end{tabular}

Note: The Total column percents read down. Each row except for the Total column reads across.

ble 2 . The affiliated students are least likely to be looking for books ( 31 percent), while nonaffiliated users mainly seek books. Thirty-two percent of both graduate students and alumni are looking for periodicals. Fifty-eight percent of the affiliated undergraduate users intend to study personal notes and texts. Forty-seven percent of the users from the private college confederation intend to study, as do 38 percent of the users from the technical institute. Affiliated graduate students are more likely to use the library for termpaper research or course assignments than undergraduate students (53 percent versus 42 percent). Personal research is the purpose for 49 percent of the staff usage, 42 percent of alumni, and 24 percent of faculty, compared to only 11 percent for all users.

Use of the library for leisure reading is the purpose in coming to the library for 12 percent of all users. Fifteen percent of the undergraduates and 7 percent of the graduate students intend to use it for leisure. Twenty-seven percent of the university staff use it for purposes of leisure, as do 24 percent of the alumni and 16 percent of the faculty.

Frequency of Use. Thirty-four percent of all users responding use the library daily, 46 percent weekly, 12 percent monthly, and 8 percent less than monthly. Forty- one percent of undergraduate students indicate daily use. By comparison, 35 percent of all faculty members and 36 percent of the staff use it daily. Of students from the private-college confederation, 12 percent of the respondents use it daily, and 46 percent weekly. For affiliated users, 87 percent of the undergraduates and 85 percent of the graduate students visit weekly or more frequently.

Use by Respondents' Major Field of Study. Table 3 presents the cross-classification of responses to questions on library use with major field of study of the respondents. Foreign-languages users are most likely seeking books. Other fields likely to seek books are mathematics, biology, letters, physical sciences, social sciences, public affairs, art, and information services. Those fields looking for magazines/journals include business administration, marketing, management, finance, accounting, psychology, education, and communications. Those users who enter with the purpose of studying personal notes and texts are in the following disciplines: physical sciences, biology, information systems, health, accounting, finance, mathematics, business administration, and marketing. The fields least likely to be in the library for personal study are: art, foreign languages, psychology, and education. Use of the library for specific 
TABLE 2

CROSS-CLASSIFICATION OF AFFILIATION

AND/OR STATUS WITH RESPONSES

ON TYPES OF LIBRARY USAGE

$(N=3356)$

\begin{tabular}{|c|c|c|c|c|c|c|c|}
\hline & Total & $\begin{array}{l}\text { Under } \\
\text { Grad }\end{array}$ & Grad & $\begin{array}{l}\text { Affiliated } \\
\text { Fac- } \\
\text { ulty }\end{array}$ & Staff & Alum. & $\begin{array}{l}\text { Pvt. } \\
\text { Inst. }\end{array}$ \\
\hline Total \% & 100 & 51 & 29 & 2 & 1 & 2 & 6 \\
\hline Uses: & $\%$ & $\%$ & $\%$ & $\%$ & $\%$ & $\%$ & $\%$ \\
\hline Books & 37 & 38 & 31 & 37 & 46 & 41 & 49 \\
\hline Magazines & 27 & 24 & 32 & 31 & 24 & 32 & 24 \\
\hline Other & 23 & 27 & 22 & 26 & 27 & 14 & 10 \\
\hline Books \& Magazines & 9 & 6 & 12 & 7 & 3 & 12 & 12 \\
\hline $\begin{array}{l}\text { Purpose } \\
\text { Study }\end{array}$ & 47 & 58 & 42 & 1 & 0 & 9 & \\
\hline Course Assgn. & 44 & 41 & 53 & 1 & 0 & 10 & $\begin{array}{l}47 \\
66\end{array}$ \\
\hline Personal & 11 & $\begin{array}{l}71 \\
11 .\end{array}$ & 9 & 24 & 49 & 42 & 9 \\
\hline Job & 6 & 4 & 5 & 13 & 39 & 29 & 5 \\
\hline Faculty & 3 & 0 & 2 & 59 & 12 & 2 & 1 \\
\hline Thesis & 5 & 1 & 10 & 2 & 0 & 2 & 10 \\
\hline Leisure & 12 & 15 & 7 & 16 & 27 & 24 & 5 \\
\hline "Other" & 8 & 9 & 7 & 13 & 6 & 3 & 1 \\
\hline $\begin{array}{l}\text { Frequency: } \\
\text { Daily }\end{array}$ & & & & & & & \\
\hline Daily & 34 & 41 & 33 & 35 & 46 & 7 & 12 \\
\hline Weekly & 46 & 46 & 52 & 55 & 33 & 41 & 46 \\
\hline $\begin{array}{l}\text { Monthly } \\
\text { Less }\end{array}$ & $\frac{12}{8}$ & $\begin{array}{l}9 \\
4\end{array}$ & 11 & 7 & $\begin{array}{r}18 \\
3\end{array}$ & 24 & 24 \\
\hline $\begin{array}{l}\text { Less } \\
\text { Meets Needs: }\end{array}$ & & & & & 3 & 29 & 18 \\
\hline All & 34 & 41 & 28 & 13 & 12 & 19 & 24 \\
\hline Most & 55 & 51 & 62 & 74 & 58 & 58 & 63 \\
\hline Some & 8 & 6 & 7 & 11 & 27 & 19 & 8 \\
\hline Seldom & 1 & 1 & 1 & 0 & 3 & 3 & 2 \\
\hline Photocopy (\% Adequacy Yes): & 67 & 70 & 59 & 62 & 70 & 53 & 81 \\
\hline
\end{tabular}

Note: Other nonaffiliated users are excluded.

course assignments or term papers is most frequently found in psychology, education, and public affairs. The fields of study that use the library least for course assignments or term papers are physical sciences, mathematics, accounting, biology, health, and information systems.

Personal research is the stated purpose for users in the fields of art, foreign languages, letters, and mathematics. On the other hand, the fields of accounting, marketing, finance, and management show a low level of usage for personal research.

Entering the library for leisure reading is the purpose of 12 percent of the users. The fields that have the highest levels of leisure reading include letters, art, biology, information systems, and mathematics. Leisure reading is more unlikely for users in the fields of education, psychology, public affairs, finance, and marketing.

Frequency of Visit. Patrons who are more likely to use the library daily are in the fields of biology, foreign languages, mathematics, accounting, and finance. Those fields more likely to use it at least once a week include public affairs, psychology, education, marketing, management, art, social sciences, business administration, communications, information systems, and health. It met all or most of the needs for 90 percent of the users in the fields of biology, business administration, education, health, mathematics, physical sciences, psychology, accounting, finance, and management.

Residential Patterns of Users. Given the central metropolitan location of the university and its status as a commuter school, the distance from the residence of the user to the library is an appropriate question. This section reports findings from the cross-classification of selected metropolitan locations with responses on its use. Location was determined on the basis of ZIP codes. A separate analysis de- 
TABLE 3

CROSS-CLASSIFICATION OF SELECTED MAJOR FIELD

OF STUDY WITH RESPONSES TO LIBRARY USAGE

\begin{tabular}{|c|c|c|c|c|c|c|c|c|c|c|c|c|c|c|c|}
\hline 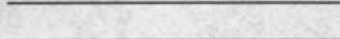 & $T$ & B & BA & C & IS & E & $\mathrm{A}$ & FL & $\mathrm{H}$ & $\mathrm{L}$ & $\mathrm{M}$ & PS & $\mathbf{P}$ & $\mathrm{PA}$ & SS \\
\hline$N$ & 3356 & 132 & 1125 & 121 & 148 & 350 & 84 & 43 & 197 & 140 & 48 & 61 & 206 & 98 & 280 \\
\hline Uses: & $\%$ & $\%$ & $\%$ & $\%$ & $\%$ & $\%$ & $\%$ & $\%$ & $\%$ & $\%$ & $\%$ & $\%$ & $\%$ & $\%$ & $\%$ \\
\hline Books: & 37 & 49 & 30 & 35 & 39 & 35 & 43 & 61 & 35 & 49 & 50 & 46 & 30 & 43 & 46 \\
\hline Magazines & 27 & 18 & 32 & 31 & 20 & 32 & 24 & 12 & 24 & 22 & 10 & 12 & 36 & 28 & 23 \\
\hline Other & 23 & 28 & 27 & 21 & 30 & 17 & 13 & 23 & 27 & 15 & 35 & 23 & 18 & 14 & 19 \\
\hline $\begin{array}{l}\text { Books \& Magazines } \\
\text { Purposes (\% Yes): }\end{array}$ & 9 & 3 & 6 & 9 & 5 & 13 & 13 & 2 & 9 & 11 & 2 & 12 & 13 & 12 & 12 \\
\hline Study & 47 & 64 & 55 & 46 & 66 & 36 & 24 & 28 & 59 & 40 & 52 & 75 & 30 & 43 & 41 \\
\hline Course Assgn. & 44 & 37 & 44 & 48 & 37 & 55 & 39 & 44 & 36 & 41 & 27 & 25 & 59 & 63 & 49 \\
\hline Personal & 11 & 14 & 7 & 15 & 9 & 11 & 23 & 23 & 9 & 22 & 17 & 15 & 11 & 15 & 14 \\
\hline Job & 6 & 2 & 6 & 7 & 5 & 7 & 8 & 2 & 5 & 6 & 8 & 3 & 4 & 10 & 7 \\
\hline Faculty & 3 & 0 & 2 & 0 & 1 & 3 & 2 & 7 & 0 & 6 & 6 & 10 & 4 & 2 & 6 \\
\hline Thesis & 5 & 4 & 2 & 2 & 1 & 8 & 6 & 2 & 3 & 7 & 0 & 5 & 10 & 12 & 10 \\
\hline Leisure & 12 & 18 & 12 & 14 & 15 & 6 & 18 & 14 & 11 & 23 & 15 & 12 & 7 & 7 & 10 \\
\hline Other & 8 & 4 & 6 & 11 & 7 & 7 & 13 & 14 & 11 & 14 & 2 & 8 & 5 & 8 & 7 \\
\hline Daily & 34 & 47 & 39 & 39 & 42 & 20 & 29 & 44 & 34 & 39 & 46 & 39 & 22 & 21 & 37 \\
\hline Weekly & 46 & 36 & 44 & 43 & 44 & 55 & 49 & 42 & 49 & 41 & 42 & 48 & 64 & 60 & 47 \\
\hline Monthly & 12 & 11 & 10 & 11 & 10 & 15 & 12 & 14 & 10 & 10 & 10 & 10 & 12 & 11 & 10 \\
\hline Less & 8 & 5 & 7 & 6 & 5 & 9 & 11 & 0 & 7 & 10 & 2 & 3 & 2 & 7 & 6 \\
\hline $\begin{array}{l}\text { Meets } \Lambda \\
\text { All }\end{array}$ & 34 & 34 & 40 & 30 & 31 & 35 & 32 & 30 & 34 & 29 & 38 & 38 & 20 & 32 & 24 \\
\hline Most & 55 & 58 & 51 & 54 & 58 & 59 & 54 & 54 & 57 & 58 & 58 & 60 & $\begin{array}{l}20 \\
70\end{array}$ & 53 & $\begin{array}{l}24 \\
64\end{array}$ \\
\hline Some & 8 & 7 & 6 & 12 & 8 & 5 & 11 & 14 & 8 & 11 & 4 & 2 & 7 & 12 & 7 \\
\hline Seldom & 1 & 1 & 1 & 2 & 1 & 1 & 1 & 2 & 0 & 1 & 0 & 0 & 2 & 3 & 3 \\
\hline Photocopy (\% Adequacy Yes) & 67 & 80 & 67 & $5 \overline{5}$ & 72 & 67 & 61 & 77 & 71 & 64 & 64 & 77 & $5 \overline{5}$ & 68 & 65 \\
\hline
\end{tabular}

Key: $\mathrm{T}=$ Total: $\mathrm{B}=$ Biology: $\mathrm{BA}=$ Business Administration $\mathrm{C}=$ Communications; IS $=$ Information Systems; $\mathrm{E}=$ Education; $\mathrm{A}=\mathrm{Art} ; \mathrm{FL}=$ Foreign Languages; $\mathrm{H}=\mathrm{Health} ; \mathrm{L}=$ Letters; M = Mathematics; PS = Physical Sciences; P = Psychology; PA = Public Affairs; SS = Social Sciences. 
termined that the pattern of residency of library users is very similar to that of the student body as a whole.

Alumni users generally live within a fifteen-mile radius of the university. Users from the private-college confederation generally live within five miles of the library and their own institution, while the residence of high-school students is generally within ten miles of the library.

Library users who have as one of their purposes general study are likely to be residing within fifteen miles of it. Users who intend to use it for the purpose of course assignments or term papers are more likely to commute two or more miles. Personal information and leisure reading are more often indicated as the purposes of users who live beyond a five-mile commuting distance.

Daily use of the library is generally associated with those users who commute the greatest distance (at least ten miles). Less than monthly use is more likely for its patrons who reside within ten miles of the university. While users living beyond a ten-mile radius reported that the library tends to meet "all" their needs, those users living within ten miles indicated that it is less likely to meet "all" their needs.

This analysis suggests that the farther the users are located from the library, the more it is likely to meet their needs and purposes. Apparently, the library serves as a valuable resource for those located in areas that do not have alternative or adequate library resources.

\section{Perceptions of Library Adequacy}

Concerning the extent to which the services and facilities of the library generally meet users' needs, 34 percent of all respondents indicate that it meets "all" their library needs and 55 percent indicate "most" needs (see table 2). For affiliated undergraduates, 41 percent indicate that it meets "all" their needs, while 28 percent of the affiliated graduate students indicate "all." Of the private-college confederation respondents, 24 percent report that it meets "all" their needs. Faculty, staff, and alumni respond that the library meets "all" their needs 13 percent, 12 percent, and 19 percent respectively.

\section{CONCLUSIONS AND DISCUSSION}

The nontraditional role being filled by the library serving nontraditional students is evidenced by findings that indicate students, faculty, staff, and alumni are more likely to use the library for purposes other than books, magazines, or journals. These "other" purposes range from using the telephone, taking a nap, resting, meeting a friend, to reading the Bible. It can be estimated that up to onefifth of the visitors do not have as their primary purpose the use of library materials. Rather, they use the library as a social resource-not an academic one.

It appears that books are a strong motivation for nonuniversity affiliated users. This heavy use suggests that the library is meeting needs that other libraries in the area cannot or do not meet. The users from the private-college confederation are particularly pleased with the services of the library. More than 50 percent of these responding private-college students visit the library weekly or daily, with 24 percent of them reporting that it meets "all" their needs. They are the most satisfied group among the library clientele.

The library's unacknowledged role in promoting and facilitating leisure reading and personal research is an area of concern to library administrators. Faculty, staff, and alumni often use the library for personal research. It was found that 12 percent of all library users-especially staff and alumni-do leisure reading. Cross-classification of primary purpose of visit with major field of study indicates that humanities users are more likely to use it for personal research and leisure reading. Conversely, the more-technical areas, including physical sciences, biology, information systems, health, accounting, finance, mathematics, business administration, and marketing tend to use the library to study personal notes and texts.

Some questions have been raised that the survey did not address. The most salient of these are: (1) Why do large subpopulations of both students and faculty not make use of the library? (2) What is the 
pattern of materials' check-outs? and (3) What factors contribute to the use of the library for nontraditional purposes? Responses to the first two questions may provide the information needed to balance acquisitions. Responses to the latter question may suggest similarities as well as differences in the function of libraries at urban universities compared to those in other types of institutions.

Finally, public dependence and reliance on the centrally located and accessible university library indicate an important com- munity service not generally recognized or specifically funded. The unexpectedly large indication of nontraditional use suggests a need for more private or quiet places-either in the library itself or apart from it-where students can collect themselves between their worlds of "work" and "school." Research at other urban universities indicate that such "social space" not only may accommodate the needs of all users, but may also enhance student retention.

\section{REFERENCES}

1. Rosemary Ruhig DuMont, "A Conceptual Basis for Library Effectiveness," College \& Research Libraries 41:103-11 (March 1980).

2. Lcwell A. Martin, "User Studies and Library Planning," Library Trends 24:483-96 (Jan. 1976).

3. DuMont, "A Conceptual Basis," p.103-11.

4. Janet Kodras and James E. Prather, Profile of Library Users (Atlanta: Georgia State University, 1978). (ED 168595$)$.

5. Jinnie Y. Davis and Stella Bentley, "Factors Affecting Faculty Perceptions of Academic Libraries," College \& Research Libraries 40:527-32 (Nov. 1979).

6. Kenneth Allen, "Student and Faculty Attitudes," Library College Journal 3:28-36 (Fall 1970).

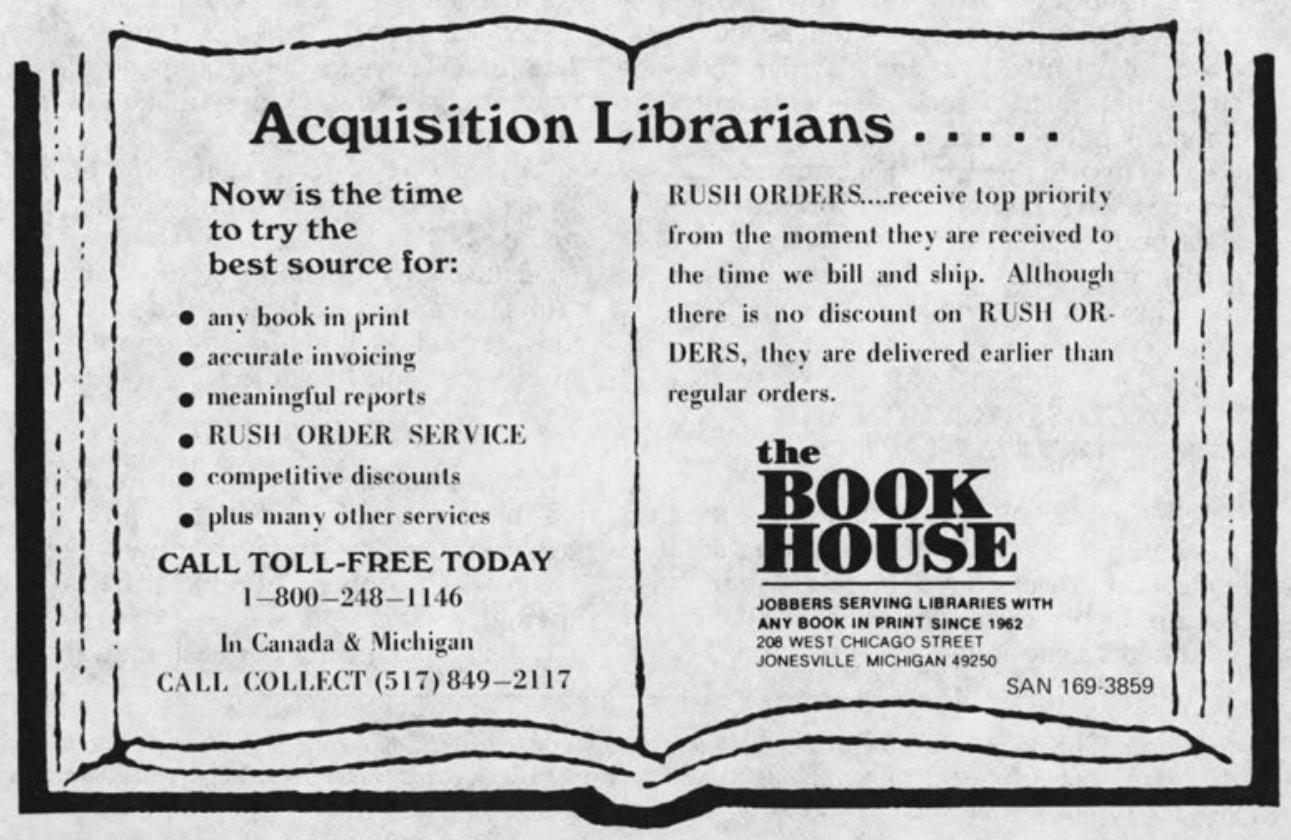

